\title{
THE POLITICAL CAREER OF GÁSPÁR BEKES AND FERENC WESSELÉNYI IN POLAND-LITHUANIA DURING THE REIGN OF STEFAN BATORY ${ }^{1}$
}

\author{
Dominik Kadzik http://orcid.org/0000-0001-8589-1508
}

Jagiellonian University in Kraków

\begin{abstract}
This article is about the career and political positions of Gáspár Bekes and Ferenc Wesselényi in the Polish-Lithuanian Commonwealth during Stephen Báthory's reign. It explains how they both achieved their positions and why they were important for the monarch. It should be emphasised that both of them are a good example of how the elected Polish king could help foreigners in their career in $16^{\text {th }}$ century Poland. On the one hand, Gáspár Bekes achieved his position by serving in the army before and during Báthory's wars, on the other hand Ferenc Wesselényi played an important role as a holder of a high office at the Polish royal court.
\end{abstract}

Keywords: Stephen Báthory, Gáspár Bekes, Ferenc Wesselényi, polish royal court, Polish-Lithuanian Commonwealth, foreigners at the royal court, $16^{\text {th }}$ century.

After the death of Zygmunt II August (r. 1548-1572), the last king of the Jagiellonian dynasty, in 1572 the Polish-Lithuanian Commonwealth became an elective monarchy. In the period 1572-1785 several monarchs on the Polish throne were foreigners, usually reluctant to adjust their political habits and ideas of royalty to the expectations of the Polish-Lithuanian gentry. As some of the newly-elected kings neither spoke Polish nor had any familiarity with the country they were to govern, they had to create their own political base of clients and loyal allies. While the royal faction was for the most part made up of men of local origin, it would also include a handful of the king's fellow countrymen and other foreigners. Their role and influence appear to have been marginal, especially when compared with the political weight of Poland's magnates and landed gentry. A typical foreigner at court had

1 The work is the result of the implementation of the research project No. 2017/27/N/HS3/01112 financed by the Narodowe Centrum Nauki (National Science Center). 
hardly any ties with the local elites and his functions were largely ceremonial, except those few occasions when his expert advice was sought by the king. Yet, it is still worth taking a second look at their role in political decision-making, their influence at the royal court and their career prospects. At any case, any promotion, no matter how petty, or any royal property gift that came their way would invariably provoke a great deal of resentment. If there was one thing that could make the warring factions in the Polish-Lithuanian Commonwealth put aside their quarrels was the preferment of the monarch's foreign favourites. Faced with such a prospect, the szlachta, in spite of all their divisions and rivalries, could always be counted on to rally around what they saw as their common cause. Alternately, it can be described as acting in the interest of one's social class, or manifestations of the division between aliens (foreigners) and natives ('home-born', 'our own'), the latter jealously guarding their privileged position. This attitude was deeply entrenched as shown by the following express provision of The Henrician Articles, a constitutional statute drawn up for King Henryk III Walezy (Henry de Valois, r. 1573-1574) in 1573:

The crown offices of both the nations must be preserved in entirety, thus we shall neither obstruct nor repress the courtly offices; but indeed, to solid and worthy people of merit, of both the nations, and not to foreigners [emphasis added, D.K.], shall [such offices] be given whenever they are vacant. ${ }^{2}$

This restriction was further strengthened by a clause in the 1576 coronation oath for Stefan Batory (r. 1576-1586). It forbade the king to acquire any private property above a certain limit for himself or his heirs without the consent of the Sejm. ${ }^{3}$ The reason for imposing this brake on the king's powers was no doubt twofold: the nobility's fear of the monarchy developing into dominium absolutum, and of foreigners in the entourage of Stefan Batory acquiring landed property in Poland. Their misgivings may have been fueled by the confusion accompanying the brief and catastrophic reign of Henry Valois. ${ }^{4}$

Obviously, the citizens of Poland-Lithuania were keen to limit the influence of aliens. And yet, the presence of all kinds of obstacles begs the question if, after all, it was possible for foreigners to play a significant role in the affairs of state or at the royal court in the Age of Elective Monarchy.

From that perspective, the reign of Stefan Batory is of prime importance. He was the second monarch to be chosen in a free election; a man of outstanding personal qualities who knew how to use royal powers effectively for the benefit of the state. His rule offers a sharp contrast to the short, messy reign of his predecessor Henry Valois, who absconded from Poland four months after his coronation. There was,

2 Volumina Legum, vol. II, Petersburg 1859, p. (152) 900 (Article 11). English translation in: http:// polishfreedom.pl/en/document/the-henrician-articles [accessed: August 1, 2019].

3 Ś. Orzelski, Bezkrólewia ksiag ośmioro, czyli dzieje Polski od zgonu Zygmunta Augusta r. 1572 $a \dot{z}$ do r. 1576. Skreślone przez Świętosława z Borzejowic Orzelskiego, starostę radziejowskiego, transl. W. Spasowicz, vol. III, Petersburg-Mohilev 1856, p. 220. The Polish text of Pacta conventa for the Polish Monarchs can be found at http://www.trybunal.gov.pl/wszechnica/akty/pacta_conventa.htm [accessed: August 1, 2019].

4 Cf. S. Grzybowski, Henryk Walezy, Wrocław 1985, pp. 107-122. 
therefore, no established practice or set of norms regulating the careers of foreigners in the entourage of a foreign-born monarch. In this respect it was Stefan Batory's reign that set a precedent to be followed, or altered, by his successors. Moreover, he was uniquely qualified to reshape the constitutional order of the Commonwealth. ${ }^{5} \mathrm{He}$ successfully initiated a number of reforms, which determined the fortunes of PolandLithuania for the following two hundred years. Chief among them was the upgrading of the role of the provincial dietines (sejmiki), the adoption of rules for the royal election, the granting of life tenure of office to the hetmans, reform of the judiciary (the creation of two appeal courts, one for the Kingdom of Poland, the other for Lithuania). As Marek Wrede rightly observed, "the years $1572-1587$. . . are perceived as a period of transition, of destabilization of royal authority and local government, the effects of which would only make themselves felt in the shifting trends of political life in the $17^{\text {th }}$ century." Surely, a handful of foreigners could hardly have influenced any of those developments, and even if they had wanted to, they would not have been allowed to interfere in issues which touched the interests of the most powerful political force in the country, the Polish nobility. That being said, Stefan Batory's countrymen did leave their mark on the army and the court, two institutions that depended directly on the king, thanks to the appointment of Gáspár Bekes and a number of Hungarian noblemen to leading posts in the military and of Ferenc Wesselényi, the king's secretary, to the post of chief of court. But we may ask, did they merely hold high offices, or, did they exert influence beyond their official roles, or, perhaps even more, did they have a hand in Stefan Batory's political reforms? The careers of Gáspár Bekes (1520-1579) and Ferenc Wesselényi (1540-1594) also provoke the perennial question about the promotion of royal favourites. That they were perceived as such both by the Polish nobility and, subsequently, by the historians of the PolishLithuanian Commonwealth there can be no doubt whatsoever.

While both Gáspár Bekes and Ferenc Wesselényi enjoyed the patronage of Stefan Batory, their careers are hardly similar, chiefly because of the nature of the institutions they were attached to.

Gáspár Bekes had built a reputation for himself as Stefan Batory's chief opponent on his home turf in Transylvania, but after all his efforts, including an armed rebellion, came to nothing, he decided to seek reconciliation with his rival, now king of Poland, and to offer him his services.

A scion of an old Hungarian noble family, Gáspár Bekes caught the eye of Jan II Zygmunt Zápolya, Prince of Transylvania (János Zsigmond, r. 1541-1571). Zápolya,

5 More on Stefan Batory's plans and his efforts to alter the constitutional order of Poland-Lithuania in E. Dubas-Urwanowicz, O nowy ksztalt Rzeczypospolitej. Kryzys polityczny w państwie w latach 1576-1586, Warszawa 2013.

6 M. Wrede, Itinerarium króla Stefana Batorego 1576-1586, Warszawa 2010, p. 35, note 58. In formulating this opinion, the author draws on the comprehensive study of A. Sucheni-Grabowska, "Sejm w latach 1540-1586" [in:] Historia sejmu polskiego, vol. 1:Doschytku szlacheckiej Rzeczypospolitej, ed. J. Michalski, Warszawa 1984, pp. 122-124. Cf. also J. Dzięgielewski, "Procesy destrukcyjne w ustroju mieszanym Rzeczypospolitej" [in:] Dziedzictwo Pierwszej Rzeczypospolitej w doświadczeniu politycznym Polski i Europy, ed. J. Ekes, Nowy Sącz 2005, pp. 69-87. 
who had no legal heir, not only made Bekes his closest advisor and lavished on him grants of land but also designated him his successor. However, after Zápolya's death in 1571, the Transylvanian Diet (the Estates) did not ratify his last will and opted instead for Stefan Batory. Bekes kept up his claim by forging an alliance with the Holy Roman Emperor, Maximilian II who assisted him in organizing two unsuccessful rebellions in Transylvania. The second one ended in a shattering defeat at the Battle of Kerelőszentpál in 1575 and the withdrawal of Maximilian II's support for Bekes. The disgraced Transylvanian rebel leader fled to Poland where he found refuge with Piotr Zborowski, the Voivod of Cracow. During the royal election crisis of 1575-1576 the Zborowskis threw their weight behind Stefan Batory, and Bekes had to leave for Hungary. Nonetheless, Piotr Zborowski did not abandon his Hungarian friend and worked successfully for a reconciliation between the new king and his erstwhile rival. ${ }^{7}$

Given his history of radical opposition to Stefan Batory, it looked fairly certain that Bekes would never find favour with the king. Yet, contrary to all expectations, it was not long before he joined the circle of Stefan Batory's closest advisors. Did the king forgive Bekes all his political sins and did he take the repentant nobleman into confidence already in the early days of his reign? The question remains open even though Polish historians seem to have made up their mind about it: they believe that full trust between the two men was restored from the moment of the reconciliation, and/or pass over the issue as not worth discussing. ${ }^{8}$ In taking this view Polish historiography follows contemporary accounts written by chroniclers, couriers and diplomats who were convinced that the relationship of trust between the king and his erstwhile deadly rival was a direct consequence of their miraculous reconciliation. ${ }^{9}$ The tone was set by Reinhold Heidenstein (Pol. Rajnold Hejdensztejn), Stefan Batory's principal secretary and a prime source of information about the king's inner circle. While he had a unique insight into the goings-on at the court, we must not ignore the political bias of his works. Nor should we assume that he wrote the whole truth, let alone he knew it. Heidenstein was, after all, a close associate of Jan Zamoyski and

7 K. Lepszy, "Békés Kasper" [w:] Polski stownik biograficzny 1935, vol. 1, pp. 401-402; F. Roşu, Elective Monarchy in Transylvania and Poland-Lithuania 1569-1587, Oxford 2017, pp. 56-57, 60, 7072, 87, pp. 164-167, https://www.oxfordscholarship.com/view/10.1093/oso/9780198789376.001.0001/ oso-9780198789376?rskey=zGUT1X\&result=1 [accessed: August 1, 2019]. Cf. also L. Szádeczky, Kornyáti Békés Gáspár, Budapest 1887.

8 Cf. J. Besala, Stefan Batory, Warszawa 1992, pp. 100, 172. Several historians do not pause to explore the peculiar nature of the interpersonal relationship between the king and Gáspár Bekes. Cf. K. Olejnik, Stefan Batory, Warszawa 2013.

9 J.Ch. Albertrandy, Panowanie Henryka Walezego i Stefana Batorego królów polskich $z$ rękopismów Albertandego. Z dołaczeniem pamiętników historii Stefana Batorego dotyczacych i listu Jerzego Chiakora, sekretarza królewskiego, opisującego ostatnie chwile tego monarchy, ed. Ż. Onacewicz, Kraków 1860, p. 144; Reinholdi Heidensteinii Secretarii Regii Rerum Polonicarum Ab Excessu Sigismundi Augusti Libri XII, Frankfurt (M) 1672 (transl. M. Gliszczyński, Dzieje Polski od śmierci Zygmunta Augusta do roku 1594. Ksiag XII, vol. I-II, Petersburg 1857). The story of the reconciliation can be found in vol. I, p. 332. 
wrote his works under the keen eye of the Chancellor. ${ }^{10}$ Recently, Felicia Roşu put the surprising rapprochement between Stefan Batory and his old enemy in a new light by citing the opinion of the Apostolic Nuncio Vincent Laureno that the king kept his friends close and his enemies closer. ${ }^{11}$ It would be hard to contest the astuteness of the Nuncio's observation given the uncertainties of the king's position at that time. On the political front, Stefan Batory had to confront a strong opposition of the Emperor's adherents in his new realm (Lithuania, Danzig, Royal Prussia as well as several senators, mostly from Wielkopolska, refused to recognize his election) and to watch out for a military intervention of Maximilian II, who had no intention of giving up his claim to the Polish throne. As for Bekes, even his assurances were genuine, there was no guarantee that the residue of his animosity, accumulated over decades, could not be stirred up again. Stefan Batory was no fool and, to be on the safe side, decided to keep Bekes in Poland rather than to let him go back home to Transylvania. As time went on, persuaded by Bekes consistently loyal service, the king not only dropped his initial caution but put as much trust in him as in any of his closest associates.

In September 1577 Gáspár Bekes was put in command of a Hungarian contingent sent to reinforce Polish troops fighting the Danzig rebels. His mission was to head off an offensive of the Danziger and the Danes against Elbing (Elbląg), a Prussian port town that sided with Stefan Batory. ${ }^{12}$ Throughout the campaign Bekes showed great courage and fine leadership. The reasons for entrusting Bekes with this difficult job must be sought both in his military experience and his descent. Even before the escalation of the conflict with Danzig Stefan Batory sent back to Transylvania the majority of his countrymen (mostly noblemen) that had accompanied him for the coronation. The only Hungarian presence left in Poland were a few regiments of infantry and cavalry. ${ }^{13}$ Even if they could not be placed under Polish command because of the language barrier, it did not necessarily restrict the king's choice of high-ranking officers who happened to be on hand. Apart from Bekes he could (and did) rely on the service of György Bánffy, Captain-General of Transylvanian Infantry, who seized the castle of Lanckorona from the rebels in $1576 ;{ }^{14}$ Mihály Vadász, who commanded

10 Cf. E. Dubas-Urwanowicz, O nowy ksztatt Rzeczypospolitej, p. 12. This assessment is shared by the editor and translator of Heidenstein's works into Polish Jan Czubek. Cf. R. Heidenstein, Pamiętniki wojny moskiewskiej [orig. De bello Moscovitico commentariorum libri sex, Kraków 1584], transl. J. Czubek, Lwów 1894.

11 F. Roşu, Elective Monarchy in Transylvania and Poland-Lithuania, pp. 167-168, https://www. oxfordscholarship.com/view/10.1093/oso/9780198789376.001.0001/oso-9780198789376?rskey=z GUT1X\&result=1 [accessed: August 1, 2019]. Cf. also T. Wierzbowski, Vincent Laureo, évêque de Mondovi, nonce apostolique en Pologne, 1574-1578, Warszawa 1887, p. 688.

12 More on the defence of Elbląg in: "List Kacpra Bekiesza do Króla jmci," Elbląg, September 17, 1577 [in:] Pamiętniki do historyi Stefana króla polskiego, czyli korespondencja tego monarchy, oraz zbiór wydanych przez niego urządzén, ed. E. Raczyński, Warszawa 1830, pp. 79-82 and R. Heidenstein, Dzieje Polski, pp. 275 and 277.

${ }_{13}$ J.Ch. Albertrandy, Panowanie Henryka Walezego i Stefana Batorego, p. 96; R. Heidenstein, Dzieje Polski, p. 246.

14 Ś. Orzelski, Bezkrólewia ksiag ośmioro, p. 259 and R. Heidenstein, Dzieje Polski, pp. 102 and 239 . 
Hungarian troops at the battle of Lubieszowa in $1577 ;{ }^{15}$ and János Bornemissza, who served as the king's envoy to the besieged Danzig and, after the death of Gáspár Bekes, took over command of the Transylvanian infantry. ${ }^{16}$ At first Bekes was just one of several Hungarian captains waiting to be engaged, but once in command he quickly built up a formidable reputation for bravery in the battlefield and for a brisk defence of Elbing against a much stronger force of the rebels and their Danish allies. Impressed by Benes's military prowess, Stefan Batory invited him to join the inner circle of royal advisors and in 1578 entrusted him with a mission requiring an extraordinary combination of military skill and political dexterity. Together with Field Hetman Mikołaj Sieniawski he was sent to Moldavia to remove the self-proclaimed Voivod (Hospodar) Alexander Potcoavă (r. 1578) and reinstate the country's legitimate ruler Peter the Lame (r. 1574-1577, 1578-1579, 1582-1591). ${ }^{17}$ After the successful completion of the Moldavian expedition, Bekes and his troops were dispatched to beef up the garrison at Kamieniec Podolski Castle, the key fortress on Poland's south-eastern border, on the eve of the war with Muscovy (the final instalment of the Livonian War). At that time Bekes, appointed commander-in-chief of the vastly expanded Hungarian regiments in Batory's service, ${ }^{18}$ played a major role in the king's plans. From 1578 onwards Bekes and his troops participated in a series of the Polish campaigns on the eastern front, most notably the taking of Polotsk (1579). ${ }^{19} \mathrm{We}$ know from contemporary accounts of the siege that the grounds round the strongly fortified Polotsk Castle were inspected jointly by king Stefan Batory, Chancellor Jan Zamoyski and Gáspár Bekes. Obviously, by that time Bekes not only enjoyed full confidence of the king but also participated in military decision-making at the highest level. He is reported to have come up with his own plans of capturing the Russian

15 "List Jana Zborowskiego kasztelana gnieźnieńskiego do króla Stefana, 18 kwietnia 1577 r." [in:] Sprawy wojenne króla Stefana Batorego. Dyjarjusze, relacyje, listy i akta z lat 1576-1586, ed. I. Polkowski, Kraków 1887, pp. 76-77. Cf. also Archiwum Główne Akt Dawnych, Archiwum Skarbu Koronnego, Rachunki Królewskie (in the following: AGAD, ASK, RK), 252, f. 76.

16 R. Heidenstein, Dzieje Polski, p. 273; "Dyariusz oblężenia i zdobycia Wieliża, Wielkich Łuków i Zawołocia od dnia 1 sierpnia do 28 listopada 1580 r., pisany przez Łukasza Działyńskiego starostę kowalskiego i brodnickiego" [in:] Sprawy wojenne króla Stefana, pp. 227, 232.

17 It is worth noting that at first Bekes was placed in command of both the Hungarian regiments and the royal guards (hufiec nadworny). However, as a result of strong opposition from the court the royal guards did not join the Moldavian expedition force. Cf. "List od jednego przyjaciela od dworu do p. Marszałka koronnego, Lwów, 3 sierpnia 1578 r." [in:] Sprawy wojenne króla Stefana, p. 124 and another letter from the same writer to the same addressee dated August 19, 1578 [in:] Sprawy wojenne króla Stefana, p. 132.

18 H. Kotarski, "Wojsko polsko-litewskie podczas wojny inflanckiej 1576-1582. Sprawy organizacyjne: Część II," Studia i Materiały do Historii Wojskowości (SMHW) 1971, vol. 17, issue 1, p. 107. The king's brother Kristóf, Voivod of Transylvania, agreed to commit some of his troops to the Moldavian expedition, see R. Heidenstein, Dzieje Polski, pp. 303 and 305. It appears that the last Transylvanian detachment arrived in Poland in June 1579. Cf. "List Stanisława Herburta, kasztelana lwowskiego do Jana Zamoyskiego, Sambor 7 czerwca 1579 r." [in:] Archiwum Jana Zamoyskiego, kanclerza i hetmana wielkiego koronnego. 1553-1579, ed. W. Sobieski, vol. 1, Warszawa 1904, pp. 343-345.

19 Cf. J.Ch. Albertrandy, Panowanie Henryka Walezego i Stefana Batorego, pp. 125-141; R. Heidenstein, Dzieje Polski, pp. 298-329. 
stronghold. At first the king did not believe they would work. Then, however, he let Bekes go ahead with his plan of assault. It proved successful thanks to the valour and dedication of the Hungarian regiments. The capture of Polotsk showed that they were the finest soldiers in the field, outshining both their Polish and Lithuanian comrades in arms. The Poles, rankled by the Hungarian superiority, did not hide their ill feeling. So, Mikołaj Mielecki, Poland's Grand Hetman, accused Bekes of usurping some of his competences and complained of the king's predilection for his Hungarian protégé ${ }^{20}$ Yet, before those murmurings could show any effect, Gáspár Bekes's brilliant career was cut off by an untimely death in 1579. It followed a rapid deterioration of his health, a consequence of his indefatigable exertions in the wars. ${ }^{21}$ By then he had collected his rewards, but, unfortunately, he was left with no time to enjoy them. In acknowledgement of his distinguished service during the 1578 campaign of the Livonian War he was presented with a grand house (known as The Rams Palace) in the Cracow Market Square. Just one year before his death he was inducted into the Polish nobility (indygenat) and given a grant of land from the royal estates. The Lanckorona estate (starostwo) was a boon: conveniently located not far from the capital, it comprised the town and castle of Lanckorona and twenty-two villages. ${ }^{22}$ The grant sent ripples through Poland's public sphere and at a sejm convened in November 1579 Lanckorona became a by-word for what some of the deputies saw as Stefan Batory's deplorable favouritism, i.e. giving away royal estates to his own countrymen. ${ }^{23}$

Although Gáspár Bekes's activities were confined to the military, various factions tried to enlist him for their own political ends. The Zborowskis, for instance, sought to exploit their old contacts with Bekes to influence Stefan Batory. The efforts made in this respect by Piotr Zborowski and Stanisław Górka indicate that they knew well Bekes's worth as an influential middleman. ${ }^{24} \mathrm{He}$ was not just a commander of the Hungarian regiment under orders, but someone both close to the king and in whom the king had great confidence. Bekes himself was also aware of the political divisions around him. There is enough evidence to show that he decided work with Chancellor Jan Zamoyski rather than continue to cultivate the political friendship with his old patron Piotr Zborowski. The clearest indication of this change of course is Bekes's offer of cooperation addressed to Zamoyski through Jan Krzysztof Drohojowski, one

20 Cf. J.Ch. Albertrandy, Panowanie Henryka Walezego i Stefana Batorego, p. 144; R. Heidenstein, Dzieje Polski, p. 324.

21 He had been ill before the campaign of 1579 , but by all accounts, he managed to recover his strength before setting off for the Russian front. The Polotsk offensive must have worn him out, and the damage to his health proved in effect fatal. Bekes's ailing health is mentioned in a letter from Father Jan Piotrowski to the Grand Marshal of Poland Andrzej Opaliński (as it turned out Bekes recovered in course of the following two weeks). Cf. also two letters to the Grand Marshal of Poland, one dated May 19, 1578 and the other June 10, 1578 [in:] Sprawy wojenne króla Stefana, pp. 106, 111.

22 Atlas Historyczny Polski. Województwo krakowskie w drugiej połowie XVI wieku. Część II, komentarz i indeksy, ed. H. Rutkowski, Warszawa 2008, p. 95.

23 R. Heidenstein, Dzieje Polski, p. 333.

24 “Urywek zapisu z rękopisu Opalińskiego, Warszawa 6 marca 1578 r." [in:] Sprawy wojenne króla Stefana, pp. 98-99. 
of closest associates of the powerful Chancellor. ${ }^{25}$ By all accounts the understanding between the two strongmen deepened during the war against Muscovy, as illustrated by the episode of the battleground inspection at Polotsk (see above). Later, when the campaign was over, they both made their way to Wilno. But the most telling evidence of the bond that had been forged between Bekes and Zamoyski is of a more private nature. While the two men went to battle Gáspár Bekes's wife Anna was staying at Knyszyn, a royal estate held by Jan Zamoyski, as a house guest of his wife Krystyna Radziwiłłówna. ${ }^{26}$

The later fortunes of Gáspár Bekes's family confirm the high status he had gained under Stefan Batory's patronage. Anna and their sons were able to hold on to the Lanckorona estate despite the opposition of the Cracow nobility. The two sons were taken care of by the king who had them sent to a Jesuit colleges in Wilno and Pultusk; after Stefan Batory's death they were looked after by Jan Zamoyski. ${ }^{27}$ Upon his brother's death, Gábor (Pol. Gabriel) Bekes, who served under Stefan Batory as captain of the Hungarian cavalry, succeed to the post of commander in chief of all Hungarian regiments in Poland. ${ }^{28}$ In 1582 Anna, Bekes's widow (née Sárkándy), married Ferenc Wesselényi, another high official and confidant of Stefan Batory. The marriage secured the position of Gáspár Bekes's heirs and was a gesture of gratitude for the longstanding protection extended to the Bekes family by Ferenc Wesselényi.

The career of Ferenc Wesselényi, the other Hungarian protégé of king Stefan Batory, took a different course from that of Gáspár Bekes's. Born into an influential Transylvanian family, he came to Poland in the entourage of Stefan Batory in 1576. Polish historians have shown little interest in Wesselényi, although it is no exaggeration to say that his position, always at the side of the king, made him a more important figure than his martial counterpart. Wesselényi's home ground was the royal court where he functioned like the most senior civil servant, uniquely qualified to take charge of any top job, not least king's special missions.

Ferenc Wesselényi remained at his post throughout Stefan Batory reign, i.e. until the monarch's death in $1586 .{ }^{29}$ The courtly function he was assigned by the king had

25 “Jan Krzysztof Drohojowski, sekretarz królewski, do Jana Zamoyskiego, Przemyśl 28 września 1578 r." [in:] Archiwum Jana Zamoyskiego, pp. 263-264.

26 “Zamoyski do żony Krystyny Radziwiłłówny, Dzisna 18 września 1579 r.” [in:] Archiwum Jana Zamoyskiego, pp. 360-361 and "Zamoyski do żony Krystyny Radziwiłłówny, Wilno 3 października 1579 r." [in:] Archiwum Jana Zamoyskiego, p. 365.

27 J.Ch. Albertrandy, Panowanie Henryka Walezego i Stefana Batorego, pp. 144, 237.

28 Cf. "Dyaryusz zdobycia zamków: Wieliża, Uświata, Wielkich Łuków w liście Jana Zborowskiego kasztelana gnieźnieńskiego do Piotra Zborowskiego wojewody krakowskiego" [in:] Sprawy wojenne króla Stefana, pp. 98-99. Henryk Kotarski claims that during the assault on Velikiye Luki Gáspár Bekes was in command of the Hungarian cavalry while the infantry regiments were led by other commanders. Cf. H. Kotarski, "Wojsko polsko-litewskie podczas wojny inflanckiej 1576-1582. Sprawy organizacyjne. Część III," SMHW 1971, vol. 17, issue 2, p. 118.

${ }^{29}$ Herbarz polski Kaspra Niesieckiego S.J. Powiększony dodatkami z późniejszych autorów rękopismów, dowodów urzędowych, vol. 9, ed. J.N. Bobrowicz, Lepzig 1842, p. 280 and E. Bu dzińska, "Franciszek Wesselini, dworzanin króla Stefana Batorego - nagrobek i 'portrety"” [in:] Polska i Europa $w$ dobie nowożytnej. L'Europe moderne: noveau monde, nouvelle civilisation? Modern Europe - New 
not existed before. In the royal household records (The Court Marshal's Book) his office is described as salariatus sive camerarius..$^{30}$ Elsewhere it is sometimes called szambelan, i.e. chamberlain, ${ }^{31}$ which would suggest that it was an equivalent of the Polish podkomorzy, or court chamberlain (class three in the court's table of ranks). There were two major reasons for the creation of a new office, whose scope to large extent overlapped that of one already in existence. First and foremost, Stefan Batory needed somebody to take control of his inner circle, a person he could trust and with whom he could communicate as freely as possible in his native language. It was only natural that this job description left out everybody except the king's countrymen. Fortunately, in Cracow there were already enough Hungarians to choose from. ${ }^{32}$ Second, Stefan Batory, at the very beginning of his reign, could hardly have wished to provoke loud protests from the Polish nobility by going ahead with the elevation of an alien to the rank of podkomorzy. The question whether the office of szambelan carried less weight, and thus giving it away to a Hungarian would cause less offence, is a matter for further study. Curiously enough, Wesselényi was sometimes addressed as toziniczy [lectistrator] (groom of the bedchamber), an office which in the Polish courtly nomenclature had hardly anything in common with that of a podkomorzy (chamberlain). ${ }^{33}$ Was the title szambelan intended to suggest a merger of the two offices? If it was merely an obfuscation, it certainly worked. The Poles could never make out the meaning of salariatus sive camerarius, or szambelan.

Wesselényi saw the king every day and probably gave him a piece of his mind on any subject that came up in their conversations. He also ushered guests into the royal chambers. One conspicuous sign of his status was a table of his own at which he sat with his subordinates. Another mark of his high rank in the courtly hierarchy

World, New Civilisation? Prace naukowe dedykowane Profesorowi Juliuszowi A. Chrościckiemu, ed. T. Bernatowicz, Warszawa 2009, pp. 529-534.

30 AGAD, ASK, RK 252, f. 21; 253, f. 88.

31 In treasury sources Piotr Nagy who held the same office as did Ferenc Wesselényi is referred to by Polish term szambelan (AGAD, ASK, RK 254, f. 322), although occasionally he is called camerarius. The Latin word is used with regard to Wesselényi as well (AGAD, ASK, RK 260, f. 12v).

32 In 1576 the court employed 87 Hungarians, mainly as junior clerks and servants. Most of them probably came to Poland from Transylvania in the retinue of Stefan Batory. Cf. AGAD, ASK, RK 246, f. $108 \mathrm{v}, 139 \mathrm{v}-140 \mathrm{v}, 143 \mathrm{v}-144,150-150 \mathrm{v}, 152 \mathrm{v}, 189-189 \mathrm{v}, 190 \mathrm{v}-191 \mathrm{v}, 198 \mathrm{v}-199,201-201 \mathrm{v}, 203$, $204 \mathrm{v}-205$, and 206-214.

33 The podkomorzy was in charge of the royal bedroom and took care of the linen, the bedclothes and proper bed-making. Apart from his main job, he could be employed in any ceremonial roles or sent on errands. There can be no doubt that both the podkomorzy (court chamberlain) and the łożniczy (groom of the bedchamber) belonged to the monarch's inner circle. Cf. U. Borkowska, Dynastia Jagiellonów w Polsce, Warszawa 2011, p. 159; M. Ferenc, Dwór Zygmunta Augusta. Organizacja i ludzie, Oświęcim 2014, p. 35; F. F uchs, "Ustrój dworu królewskiego za Stefana Batorego" [in:] Studia historyczne ku czci prof. Wincentego Zakrzewskiego, Kraków 1908, pp. 88-89 and Z. Góralski, Urzędy i godności dawnej Polsce, Warszawa 1983, p. 143. 
was the size of his retinue. ${ }^{34} \mathrm{He}$ had the right to keep ten to twelve horses, at par with the marshal or court treasurer. ${ }^{35}$ Wesselényi was busy man and his diverse activities have left a broad track record in the sources. During Stefan Batory's journey to Lwów Wesselényi (together with Kacper Maciejowski) was in charge of the royal stable, acted as an intermediary between the officials of the royal court and the captains of the Hungarian cavalry, he issued orders to other Hungarians, supervised the king's wardrobe, directed the purchase of silver plate, and acted as master of ceremonies, among others at the wedding of Gryzelda Batorówna and Jan Zamoyski. ${ }^{36} \mathrm{He}$ was also responsible for some of Poland's missions abroad, and, occasionally, carried important letters from the king to Polish and Lithuanian dignitaries. ${ }^{37}$ In the main, however, he was an informal chief of the Hungarians at the Polish court and took over the competences of the court chamberlain due to the nearly permanent absence of podkomorzy Andrzej Tęczyński. Thus, Wesselényi became de facto one of the most important personages in the king's inner circle. What is more, he was the only foreigner of Stefan Batory's reign who succeeded in gaining such an important position despite all the obstacles (e.g. the Henrician Articles, various formal barriers, and the xenophobic opposition of the szlachta and political factions). The fact that he would often take over other people's business and that he had both the confidence and the backing of the king - without which he would not have been able to operate in this way - justifies calling him the éminence grise of Stefan Batory's court. However, it needs to be added, what also helped him to concentrate so much power in his hands was the chronic absenteeism of some senior officials. As it happened, neither the two marshals nor podkomorzy Andrzej Tęczyński cared to stay for longer in the royal entourage. Their absences resulted in the machine of government being clogged up and a state of confusion which could not but annoy the king himself. ${ }^{38}$ It should come as no surprise that in such circumstances he would turn to Wesselényi, who, in consequence, took control of some of the courtly personnel.

Wesselényi's stature and influence kept growing all the time, but a turning point in his career came when he began to build up his own network of clients. So on his recommendation Wacław Kielczowski [Kiełczewski] was given the post of komornik (camerarius). ${ }^{39}$ On another occasion he worked hard to secure a grant of land in Royal Prussia to Mikołaj Bucella. Stefan Batory at first did not want to hear of it, but eventu-

34 Cf. AGAD, ASK, RK 253, Part II, f. 4v, 5v, and 7v-8. Moreover, Wesselényi's servants were provided, as part of their wage, with linen cloth, which was most unusual. They were the only group of retainers entitled to this form of payment (cf. AGAD, ASK, RK 263, f. 165; 268, f. 267-267v; 269, f. 298-298v).

35 Cf. AGAD, ASK, RK 253, Part II, f. 29 and 71; 256, f. 78; 257, f. 89v and 258, f. 35v.

36 Cf. AGAD, ASK, RK 254, f. 325; 255, f. 51; 256, f. 118v (255v), 195-195v, 238v, and 240v; 257, f. 47 and 119; 261, f. 239-239v, 251-251v, 266, and 268-268v; 263, f. 165, and 300-301; 267, f. 21, 22v, 58-58v, and 153; 268, f. 275v-276, and 280; 269, f. 308v-309; and 278, Part II, f. 83v and 85v.

37 For example, in 1580 he looked after an embassy from the Khan of Crimea. Cf. AGAD, ASK, RK 260, f. 54-54v.

38 "Powrót króla Stefana Batorego z wojny inflanckiej do Warszawy" [in:] Sprawy wojenne króla Stefana, p. 391.

39 AGAD, ASK, RK 253 f. 147v. 
ally gave in to Wesselényi's entreaties. ${ }^{40}$ Even if such interventions were exceptional, their significance must not be underrated. Wesselényi, after all, was neither a court official of the highest rank nor a public figure with much wealth and political clout. Moreover, he functioned in a country whose legal system and popular sentiment were largely hostile to foreigners in high places. To get Wesselényi's stupendous, if rather inconspicuous, career in perspective it would be necessary to compare it to other instances of royal patronage extended to foreigners (paying due attention to all the critical caveats). Even in the case at hand it is easy to overstate the depth or persistence of the Polish and Lithuanian nobles' animosity to Stefan Batory's foreign favourite. The real litmus test of their attitude was the wedding of Ferenc Wesselényi and Gáspár Bekes's widow, Anna in 1582. Apart from the royal couple it was attended by several Polish and Lithuanian senators, among them Jan Działyński, Voivod of Chełmno (Kulm) and Stanisław Tarnowski, Castellan of Sandomierz. Wedding gifts were sent by Stanisław Karnkowski, Archbishop of Gniezno and Primate of Poland and Mikołaj Krzysztof Radziwiłł, Grand Marshal of Lithuania. ${ }^{41}$ What is more, the wedding was hosted by king Stefan Batory himself, the invitations were issued by him personally and he presided over the ceremonies and the reception which took place at the royal castle of Knyszyn. ${ }^{42}$ It is hard to imagine a more striking display of royal patronage.

The fast-track rise of Ferenc Wesselényi at Stefan Batory's court was followed by emoluments that raised his material status. In 1578 in acknowledgment of his loyal service he was granted the tenancy of the royal estate (starostwo) of Lipnik (Ger. Kunzendorf). It was by all standards a rather modest gift: the state consisted of a small town and three villages. ${ }^{43}$ Curiously enough, his services at court went unpaid (he received no salarium); instead, he was entitled, according to the Court Marshal's Book, to have free meals (at his own table), a daily supply of wine for himself and forage for his horses. According to the treasury accounts the annual cost of these provisions amounted to 3,773 florins and 20 groschen. ${ }^{44}$ It was however the marriage with Gáspár Bekes's widow that made Wesselényi a man of respectable wealth. Apart from Lipnik his possessions now included the Lanckorona estate and The Rams House in Cracow. In addition, in 1583 he bought Dębno Castle, the place where he retired after the death of king Stefan Batory. ${ }^{45}$

The last months and days of Stefan Batory show how special was the relationship between the two men. As his health rapidly deteriorated the king ordered everybody to clear the royal chambers and the keys to those rooms and his private treasure

40 Co warte odnotowania, to Buccellę wspierał także Paweł Gyulay, kanclerz siedmiogrodzki. Cf. A. Knot, "Dwór lekarski Stefana Batorego" [in:] Archiwum historii i filozofji medycyny oraz historii nauk przyrodniczych, ed. A. Wrzosek, vol. VIII, Poznań 1928, p. 180.

41 "List x. Jana Piotrowskiego do Pana Marszałka Koronnego, Beliniec, 26 czerwca 1582 r." [in:] Sprawy wojenne króla Stefana, p. 360.

42 "List x. Jana Piotrowskiego do Pana Marszałka Koronnego, Ludniki na Żmudzi z 14 kwietnia 1582 r.” [in:] Sprawy wojenne króla Stefana, p. 349.

43 Atlas Historyczny Polski, p. 97.

44 AGAD, ASK, RK 252, f. 21.

45 There, in 1589, he played host to Hungary's greatest Renaissance poet, Bálint Balassi. Cf. E. Budzińska, Franciszek Wesselini, s. 530. 
chest to be handed over to his secretary. Nobody but Wesselényi was to decide who could enter the premises; even the chancellors were not allowed to do so without his confidant's permission. It was then that Wesselényi resolved - without consulting anybody - to call in Mikołaj Buccelli, one of Stefan Batory's personal physicians, who was away in his estate not far from Grodno. As the assembled medics could not agree on the right treatment, they asked Wesselényi to settle their dispute. On the king's last day of life Polish and Lithuanian senators were waiting at the door of the royal bedroom for Wesselényi to come out and update them about the king's condition. And it was from Wesselényi that they got the news of the monarch's death. ${ }^{46}$

It is noteworthy that nobody dared to question the king's last orders which effectively shut him out from members of the country's political elite. The only person left at the bedside of the dying monarch was his personal secretary about whose future he seemed to take special care. In his last will the king sought to defend Wesselényi against possible allegations of wrongdoing and implored them not to strip him of any of the grants and honours he had received as a reward for loyal service. ${ }^{47}$ As it turned out, not only was the will of the deceased monarch treated with due respect but, in a gesture of goodwill, Wesselényi was allowed to a place of honour at Stefan Batory's funeral. ${ }^{48}$ In this way the country's political elite showed that they had no wish to dissent from the king's high opinion of his closest associate. There was yet another reason for Wesselényi's carrying on safely after the death of his mighty patron. The letters of Queen Anna Jagiellon to Wesselényi written after 1586 unequivocally suggest that she too was ready to shield and protect him from any harm. Her correspondence shows an emotional involvement and genuine concern; she even goes so far as to give him assurances of personal safety. ${ }^{49}$ The Queen's letters offer another proof of Wesselényi's very special role in the courtly ranks in the final years of Stefan Batory's reign.

In conclusion, what this article argues is that the extraordinary career of Gáspár Bekes and Ferenc Wesselényi at Stefan Batory's court depended largely on the patronage of the king himself. Either of them functioned in his own particular field. While Bekes was as important agent of the king's military policy, Wesselényi was a permanent caretaker of Stefan Batory's inner circle. Presumably, both of them were chosen for the same reasons. Stefan Batory needed somebody to command the Hungarian military contingent that remained in Poland and, likewise, somebody to take charge of the Hungarian expatriates at the court. It was only natural that he filled the two positions with his compatriots, i.e. who shared his cultural background and with whom he could communicate in his native language. To ensure their proper functioning, he created for them special offices that had no precedent in the institutional histo-

46 Zbiory pamiętników historycznych o dawnej Polsce. Z rękopisów, tudzież różnych dziet w różnych językach o Polszcze wydanych oraz z listami oryginalnemi królów i znakomitych ludzi w kraju naszym, ed. J.U. Niemcewicz, vol. II, Warszawa 1822, pp. 442-449.

47 "Króla JMści Stefana Batorego testamentu relacyja" [in:] Sprawy wojenne króla Stefana, p. 411412.

48 Zbiory pamiętników historycznych, pp. 453, 458, 462-463.

49 Magyar Nemzeti Levéltár, fond P 702 (Wesselényi család), sygn. 2, Doc. 4, 5, and 6. 
ry of the Polish-Lithuanian state. What is more, both Bekes and Wesselényi tended to take over other people's competences (on the face of it as stand-ins), e.g. those of the Grand Hetman of Poland and the Court Chamberlain respectively. These encroachments provoked protests both from individuals like Hetman Mikołaj Mielecki and the Polish nobility at large. The szlachta was strongly opposed to foreigners controlling the inner circle of the ruling monarch and yet it did happen for, as I have tried to prove, it was the king's intention to install his own men in positions of responsibility and to have them expand their powers and influence.

\section{BIBLIOGRAPHY}

\section{Primary Sources}

Archiwum Główne Akt Dawnych

Archiwum Skarbu Koronnego, Rachunki Królewskie: 246, 252, 253, 254, 256, 257, 258, 260, 261, 263, 267, 268, 269, 278.

Magyar Nemzeti Levéltár, fond P 702 (Wesselényi család), sygn. 2, Doc. 4, 5, and 6.

\section{Primary Sources Published}

Archiwum Jana Zamoyskiego, kanclerza i hetmana wielkiego koronnego. 1553-1579, ed. W. Sobieski, vol. 1, Warszawa 1904.

Heidenstein R., Pamiętniki wojny moskiewskiej [orig. De bello Moscovitico commentariorum libri sex, Kraków 1584], transl. J. Czubek, Lwów 1894.

Orzelski Ś., Bezkrólewia ksiag ośmioro, czyli dzieje Polski od zgonu Zygmunta Augusta r. 1572 aż do r. 1576. Skreślone przez Świętosława z Borzejowic Orzelskiego, starostę radziejowskiego, transl. W. Spasowicz, vol. III, Petersburg-Mohilev 1856.

Pacta conventa for the Polish Monarchs, http://www.trybunal.gov.pl/wszechnica/akty/pacta_conventa.html [accessed: August 1, 2019].

Pamiętniki do historyi Stefana króla polskiego, czyli korespondencja tego monarchy, oraz zbiór wydanych przez niego urządzeń, ed. E. Raczyński, Warszawa 1830.

Reinholdi Heidensteinii Secretarii Regii Rerum Polonicarum Ab Excessu Sigismundi Augusti Libri XII, Frankfurt (M) 1672 (transl. M. Gliszczyński, Dzieje Polski od śmierci Zygmunta Augusta do roku 1594. Ksiag XII, vol. I-II, Petersburg 1857).

Sprawy wojenne króla Stefana Batorego. Dyjarjusze, relacyje, listy i akta z lat 1576-1586, ed. I. Polkowski, Kraków 1887.

Volumina Legum, vol. II, Petersburg 1859, p. (152) 900 (Article 11), http://polishfreedom.pl/ en/document/the-henrician-articles [accessed: August 1, 2019].

Zbiory pamiętników historycznych o dawnej Polsce. Z rękopisów, tudzież różnych dziet w różnych językach o Polszcze wydanych oraz z listami oryginalnemi królów i znakomitych ludzi w kraju naszym, ed. J.U. Niemce wicz, vol. II, Warszawa 1822. 


\section{Literature}

Albertrandy J.Ch., Panowanie Henryka Walezego i Stefana Batorego królów polskich z rękopismów Albertandego. Z dołaczeniem pamiętników historii Stefana Batorego dotyczacych i listu Jerzego Chiakora, sekretarza królewskiego, opisującego ostatnie chwile tego monarchy, ed. Ż. Onacewicz, Kraków 1860.

Atlas Historyczny Polski. Województwo krakowskie w drugiej połowie XVI wieku. Część II, komentarz $i$ indeksy, ed. H. Rutkowski, Warszawa 2008.

Besala J., Stefan Batory, Warszawa 1992.

Borkowska U., Dynastia Jagiellonów w Polsce, Warszawa 2011.

Budzińska E., "Franciszek Wesselini, dworzanin króla Stefana Batorego - nagrobek i 'portrety"' [in:] Polska i Europa w dobie nowożytnej. L'Europe moderne: noveau monde, nouvelle civilisation? Modern Europe - New World, New Civilisation? Prace naukowe dedykowane Profesorowi Juliuszowi A. Chrościckiemu, ed. T. Bernatowicz, Warszawa 2009.

Dubas-Urwanowicz E., O nowy ksztalt Rzeczypospolitej. Kryzys polityczny w państwie w latach 1576-1586, Warszawa 2013.

Dzięgielewski J., "Procesy destrukcyjne w ustroju mieszanym Rzeczypospolitej" [in:] Dziedzictwo Pierwszej Rzeczypospolitej $w$ doświadczeniu politycznym Polski i Europy, ed. J. Ekes, Nowy Sącz 2005.

Ferenc M., Dwór Zygmunta Augusta. Organizacja i ludzie, Oświęcim 2014.

Fuchs F., "Ustrój dworu królewskiego za Stefana Batorego" [in:] Studia historyczne ku czci prof. Wincentego Zakrzewskiego, Kraków 1908.

Góralski Z., Urzędy i godności dawnej Polsce, Warszawa 1983.

Grzybowski S., Henryk Walezy, Wrocław 1985.

Herbarz polski Kaspra Niesieckiego S.J. Powiększony dodatkami z późniejszych autorów rękopismów, dowodów urzędowych, vol. 9, ed. J.N. Bobrowicz, Lepzig 1842.

Knot A., "Dwór lekarski Stefana Batorego" [in:] Archiwum historii i filozofji medycyny oraz historii nauk przyrodniczych, ed. A. Wrzosek, vol. VIII, Poznań 1928.

Kotarski H., "Wojsko polsko-litewskie podczas wojny inflanckiej 1576-1582. Sprawy organizacyjne: Część II," Studia i Materiały do Historii Wojskowości (SMHW) 1971, vol. 17 , issue 1 , pp. 51-124.

Kotarski H., "Wojsko polsko-litewskie podczas wojny inflanckiej 1576-1582. Sprawy organizacyjne. Część III,” SMHW 1971, vol. 17, issue 2, pp. 81-151.

Lepszy K., "Békés Kasper," Polski słownik biograficzny 1935, vol. 1, pp. 401-402.

Olejnik K., Stefan Batory, Warszawa 2013.

Roşu F., Elective Monarchy in Transylvania and Poland-Lithuania 1569-1587, Oxford 2017.

Sucheni-Grabowska A., "Sejm w latach 1540-1586" [in:] Historia sejmu polskiego, vol. 1: Do schyłku szlacheckiej Rzeczypospolitej, ed. J. Michalski, Warszawa 1984.

Szádeczky L., Kornyáti Békés Gáspár, Budapest 1887.

Wierzbowski T., Vincent Laureo, évêque de Mondovi, nonce apostolique en Pologne, 1574-1578..., Warszawa 1887.

Wrede M., Itinerarium króla Stefana Batorego 1576-1586, Warszawa 2010. 